\title{
Parental and Familial Factors Among Latino Youths' Successful Matriculation into Postsecondary Education
}

\author{
Sarah P. Maxwell
}

\begin{abstract}
Extant research focuses on the "educational attainment gap," documenting the lack of parity among Latino youth and other high school graduates in college matriculation. This study reversed that question, and asked instead, what factors, and specifically what parental or family-related factors, contribute to Latino youth enrolling in four-year post-secondary institutions where future earnings tend to be higher than two-year colleges. Data from the Texas Higher Education Opportunity Project (THEOP, 2004) were analyzed to identify parental contributors to successful matriculation into post-secondary education. Findings indicate that parents attending college was one of the most important indicators of Latino enrollment in either a two- or four-year college or university. Also significant, and potentially critical in social welfare policy, was rewarding students for grades. Parents helping with and checking homework were not helpful in youths' progression to postsecondary education.
\end{abstract}

Keywords: Latinos, higher education, parental involvement, homework, grades, policy

Scholarly work repetitively paints a picture of an educational attainment gap between Latino youth and their non-Latino counterparts. ${ }^{i}$ Latinos are less likely to attend college than non-Latino whites or African Americans (Brindis, Driscoll, Biggs, \& Valderrama 2002). Latino youth are also more likely to enroll in two-year, rather than four-year colleges. Yet, Latino youth and their parents overwhelmingly believe that going to college, whether a two-year or four-year institution, is important after high school (Lopez, 2009). Disparities in family income such as first-generation college experiences, poor preparation for college, and difficulties financing college are all well-documented challenges confronting Latino youth (Hurtado, Sáenz, Santos, \& Cabrera, 2008). The result is a clear underrepresentation of Latino youth in accredited institutions of higher education (National Center for Education Statistics [NCES], 2003). This trend becomes more apparent at four-year institutions, which realize lower matriculation rates among Latinos than two-year colleges (Fry, 2011). Fry (2011) notes that "Although the college enrollment rate of young Hispanics is at a record (32\%), black (38\%), Asian (62\%) and white $(43 \%)$ young adults continue to be more likely than young Hispanics to be enrolled in college" (p. 3). Even with a recent boom in Latino enrollment in post-secondary education, Latinos continue to be the population least educated by the United States, as only 13 percent of Latino adults complete a bachelor's degree (National Center for Educational Statistics, 2011). In comparison, 53\% percent of Asians, 39\% of whites, and 19\% of African Americans complete a bachelor's degree (Fry, 2011).

Sarah P. Maxwell, Ph.D., is an Associate Professor of Public Affairs and Social Policy at the University of Texas at Dallas. This research used public data from the Texas Higher Education Opportunity Project (THEOP) and the author acknowledges the following agencies that made THEOP data available through grants and support: Ford Foundation, the Andrew W. Mellon Foundation, the William and Flora Hewlett Foundation, the Spencer Foundation, National Science Foundation (NSF Grant \# SES-0350990), the National Institute of Child Health \& Human Development (NICHD Grant \# R24H0047879), and the Office of Population Research at Princeton University.

Copyright (C) 2013 Advances in Social Work Vol. 14 No. 1 (Spring 2013), 125-145 
Fortunately, a new wave of Latino youth is entering college. Enrollments in two-year colleges are increasing among Latinos (as well as other groups) as a result of the lower costs associated with community colleges versus four-year institutions. Just as women's earnings are generally below men's in the aggregate, minorities too must outperform whites in the world of education to level the playing field. US News and World Report states: "Latinos and African-Americans with master's degrees earn nearly the same in their lifetimes - roughly $\$ 2.5$ million - as white workers who have bachelor's degrees" (Burnsed, 2011, p.1). Therefore, earning at least a bachelor's degree becomes critical for women and minorities. Latinas seem dually at risk without a four-year college degree. Thus, the educational gap continues, but so do the outcomes of public policy. In other words, education is a necessity, but not a sufficient means to ameliorating the earnings disparities for Latinos.

Rather than continuing the discourse about the educational and earnings gaps for Latinos, this study employed a "what works" approach. Indeed, one of the few studies examining Latinos' successes noted that, "less is known about what distinguishes individual Latinos who enroll in college from those who do not. As a result, there is limited information on "what works for the Latino population"" (Zarte \& Gallimore, 2005, p. 384). Scholars contend that student-related activities are successful in leading Latino and minority youth to post-secondary education, such as mentoring, cultural competence in schools, and improved student engagement activities (Maxwell \& Connell, 2013). Defining the positive variables in the educational pipeline is critical. This study, therefore, applied Critical Race Theory (CRT) to known factors that influence college enrollment: family dining, parental involvement, parental education, and rewarding grades.

\section{Literature Review}

\section{Education Matters, but Culture, Education, and Expectations are Intricately Linked}

CRT as a framework depicts the cumulative effect of educational experiences on student matriculation outcomes into postsecondary education. CRT is applied to known factors that influence college enrollment for youth generally: family dining, parental involvement, parental education, and parental reward for grades. For social workers, advocacy and implementation of cultural competence are key, but overcoming multiple challenges involves schools, families, and students themselves.

The lack of understanding around education, culture, and pathways to success may not rest in one macro-focused answer such as discrimination, however, education, culture, and expectations are intricately linked. Thus, CRT is employed as an overarching analytical framework, which allows for a more nuanced approach to questioning why parental and familial differences might be present among varying groups.

CRT, as a theoretical framework in this study, did not imply outright discrimination, but rather a more nuanced application taken from Delgado and Stefancic (2012), which suggested that racism is defined as the "ordinary daily life of people of color, and the way society goes about daily life" (p. 7). Racism, or purposeful discrimination, as an 
advocacy approach was not the intended outcome of this paper. Rather, the theory highlighted the notion that Latinos face daily differences in school that help define the educational gap to improve "what works."

Some factors available included those that might distinguish among groups. For example, some scholars commented that immigration status, and therefore discrimination, was not the true perpetrator in the educational gap, noting that those from Asian countries with the same immigration status as those from Latin American countries tended to equal or surpass native-born Americans in college enrollment (Baum \& Flores, 2011; Portes, Fernández-Kelly, \& Haller, 2009). But Delgado and Stefancic (2102) offered an interesting scenario: suppose the term "Asian" was used to describe both a recent Hmong immigrant from a rural background, or a Chinese student who has lived in the United States her entire life with highly-educated parents. Baum and Flores (2011) explained that more research was needed to assess differences among immigrant groups, as well as effective policies to improve secondary education for immigrants or generations of families. Factors such as time in the United States, parental education, and immigration status served as appropriate indicators of such differences under the framework of CRT. The data set in this study allowed for examination of parental education, but not immigration status. Yet, as Tienda and Mitchell (2006) pointed out, the vast majority of Hispanics in the United States (about 70\%) are born abroad or are born to immigrant parents.

Without a doubt, cultural and familial factors were important in the research findings regarding Latinos in postsecondary education, but educating parents or offering support to families has historically been ignored as a policy response. CRT takes the stance that the daily lives of Latinos are lived in a discriminatory world. A modified CRT approach takes into account not only the daily lives of other cultures in a mostly white world, but also the inherent struggles any group might face when entering a culture with a different language. Consequently, both immigrant and native-born Hispanics found the college experience elusive in relation to native-born whites. Tienda (2009) stated:

One manifestation of low parental education is the delayed school enrollment of Hispanic preschool-age children. Although the share of Hispanic 3- and 4-yearolds enrolled in a preschool program rose slightly between 1980 and 2000, from 28 to 36 percent, the Hispanic-White differential rose, placing larger numbers of Hispanic children at a relative disadvantage during the crucial early years (p. 18).

In a social work context, secondary educators may face burdens that could be addressed by working with families in the home or through after school programs. Educators also faced challenges in finding "what works," as they too succumbed to myths about immigrant, and specifically, Latino families. Although studies consistently showed that Latino parents held high expectations of their children, teachers and administrators often believed the opposite; that Latino parents were ambivalent about educational attainment. Indeed, one study found that the simple failure of schools to send newsletters, lunch menus, and other correspondence in Spanish was one of the primary reasons Latino parents were not involved in their children's education (Smith, Stern, \& Shatrova, 2008). 
Research also contended that familial factors included a lack of parental involvement in children's education. Parental involvement was defined in a variety of ways, including the lack of formal education among Latino parents; the lack of participation in children's education (National Women's Law Center, 2009); the frequency of parent-teacher contacts; the quality of parent-teacher interactions (Izzo, Weissberg, Kasprow, \& Frendrich, 1999); and attendance at parent-teacher conferences and back-to-school nights, as expressed by teachers and administrators in another study (Zarate, 2007).

Schneider, Martinez, and Owens (2006) reported that Hispanic students, more so than either African American or white students, tended to have poor relations with their middle school teachers. Additionally, the unfortunate combination of lower literacy from inadequate primary schooling, concentrated populations in urban middle schools, and lack of a quality rapport with their teachers only reduced the Hispanic student's motivation levels, which created a cycle of potential life points where poor performance might result. Tienda (2009) summarized: "several risk factors that undermine college success, including low parental education, limited financial resources and insufficient access to information about college. Each has direct implications for the likelihood of completing the baccalaureate degree" (p. 21).

These simple, yet recurring "daily life" aspects as connoted in CRT, can easily be addressed through policy. Culturally, one study pointed to the reluctance of Latino families to question authority or advocate for their children within the school system (Smith et al., 2008). A picture begins to form that paints expectations, two-way communication, and myths about Latino family involvement that is solidified in daily life for Latinos in a sometimes rigid American educational system.

\section{Educational and Social Welfare Policy}

Public policy is now recognizing the cultural-educational link. Education as a means to upward mobility is a concept that has recently weaved its way into the U.S. immigration policy fabric. President Obama proposed a number of programs for Latinos in 2011 aimed at improving educational attainment (Koebler, 2011). Among the programs are funding increases for Head Start, as well as the training of Latino teachers, who are believed to be more effective with Latino students (Koebler, 2011).

Education matters. Although federal, state, and university policies are changing to accommodate Latinos, regardless of their immigration status, the familial factors that define the educational gap have not been widely researched or reported. Additionally, policies regarding college admissions, scholarships, and other enrollment benefits vary from state to state. Findings related to low educational attainment have spawned a considerable amount of research on student engagement, with limited focus on family life. Parental and familial factors have also been ignored in public policy. Of course, the underlying reasons for any lack of involvement by Latino parents run deeper than what can be captured in many studies, including this one. Parental factors as public policy problems are potentially exasperated when the total number and proportion of Latinos in the United States are considered. The U. S. Census reports that by 2036, one third of all U. S. school-aged children will be Hispanic (U. S. Census Bureau, 2008). 
Zarate and Burciaga (2010) explain that although an increase in Latino college enrollment is taking place, that increase is explained primarily by significant growth in community college enrollment. They suggest that enrollment into four-year degree programs may be more beneficial. "The low college enrollment and skewed distribution of enrollment into community college is the consequence of disparate educational experiences between white and Latino students" (Zarate \& Burciaga, 2010, p. 25). Another recent study points to a significantly lower rate of life time earnings for Latinos, predominately at lower educational levels (Carnevale, Rose, \& Cheah, 2010). In this study, all racial and ethnic groups with either some college or an associate's degree earned significantly less than those with a bachelor's. At the bachelor's level, however, Latinos grossed lifetime earnings at approximately the same rate as African Americans, but below both whites and Asians (Carnevale et al., 2010). Education is simply essential for earning more, but even with the additional education, social barriers to lifetime earnings remain a factor in the lives of Latinos.

Policy recommendations, as a result of these barriers, include strategies to help ameliorate the perceived problems. These include mentoring, improving teacher quality, or occasionally expanding parental involvement in schools. However, many of these concepts have yet to be fully tested. Do strategies such as helping with homework, punishing or rewarding grades, or spending more time with one's children improve outcomes for Latino youth? Many studies demonstrating the positive benefits of improved parental involvement failed to address the issue by race or ethnicity. This study examined the diverse factors in the literature, and specifically analyzed positive indicators of Latino youths' matriculation from high school to postsecondary enrollment at the bachelor's level.

\section{Parental and Familial Factors in College Matriculation}

\section{Family Dining}

CRT supports the assumption that broader societal and economic forces are at play in education. Perna (2006) and Rowan-Kenyon, Bell, and Perna (2008) offer a comprehensive contextual model for assessing pathways to college enrollment. These include: "students and their families; K-12 schools; higher education institutions; and broader societal, economic, and policy contexts" (Rowan-Kenyon et al., 2008, p. 566). CRT supports this model by assuming that broader societal and economic forces are at play. Family dining literature suggests that the relationship within families is an important determinant in postsecondary matriculation. Given the nature of CRT, family dining is a potential protective factor against daily life in schools and the potentially negative societal factors that limit success for racial or ethnic groups struggling to fit into the school milieu.

Multiple studies over the years have pointed to the importance of family dining in educational attainment. Regular family dining was one indicator of the amount of time families spend together in general. One of the most authoritative studies on family dinners, The Importance of Family Dinners at the National Center on Addiction and Substance Abuse (CASA) at Columbia University (National Center on Addiction and Substance Abuse, 2003, 2011) found that students who share family dinners with their 
parents are more likely to earn higher grades. According to the study, the benefits extend far beyond grades, showing reductions in stress and boredom, and thus, reductions in alcohol and substance abuse (National Center on Addiction and Substance Abuse, 2003, 2011).

Other studies demonstrated clear inverse relationships between family meals and a variety of negative outcomes, not at one point in time, but sometimes years later (Eisenberg, Olson, Neumark-Sztainer, Story, \& Bearinger, 2004). The problems often associated with preventing college matriculation such as low grades, substance abuse, depressive symptoms, and suicide attempts were shown to be mitigated with more frequent family dinners during the week.

To date, the research examining race and ethnicity, which might disaggregate the family dinner data, is virtually nonexistent. A few studies distinguished gender differences, with females generally experiencing positive benefits further in time (Eisenberg et al., 2004). Yet, differences among race or ethnicity were assumed to be constant. On the strength of existing research, these hypotheses are offered:

- H1a: The more frequently Latinos eat dinner with their family, the more likely they will be to enroll in college at any level.

- H1b: The more frequently Latinos eat dinner with their family, the more likely they will be to pursue bachelor's degrees.

\section{Parental Involvement in Academic Preparation}

Extant research on parental involvement in a student's success crossed two areas of interest that suggest Latinos, and other immigrant groups, deserve a separate analysis. First, parental involvement in homework as an indicator of successful college matriculation was found to be positive and significant in studies of college-bound high school students (Henderson \& Mapp, 2002; Smith et al., 2008). Second, Latinos warrant a separate analysis as a result of the role CRT plays in the lives of students and parents. Latino parents were susceptible to misunderstanding their role in their children's education as a result of school communication policies and procedures, as well as language fluency. Checking homework, helping with homework, and meeting with teachers were not clearly defined involvement activities for parents in most instances. Language barriers also played a role. Zarate (2007) stated, "For many [Latino] parents, language [is] an insurmountable barrier to participation in their children's academic tasks. Moreover, as their children [in the study] progressed through school, the content and course material became increasingly difficult to understand" (p. 9).

Parental involvement usually encompassed two factors: life participation and academic involvement (Zarate, 2007). Life participation was defined as monitoring peer groups, school attendance, exercising discipline, and observing the school environment (Zarate, 2007). Academic participation was separate and distinct and included attending parent-teacher conferences, helping with homework, and keeping track of report cards, among other variables (Zarate, 2007). In this study, the focus was academic, employing analyses that reflected levels of parental involvement with teachers and homework. 
Involvement was operationalized as helping with homework, checking homework, and meeting with teachers.

\section{Parental Involvement and College Matriculation}

Generally speaking, lower parental involvement in schooling led to lower achievement for students, while higher parental involvement resulted in improved achievement (Henderson \& Mapp, 2002; Smith et al., 2008). Such involvement began early, and research demonstrated that parental expectations and literacy development as early as kindergarten could influence academic outcomes much later in school (Froiland, Peterson, \& Davison, 2013). Across the board, researchers generally agreed that parental involvement resulted in improved expectations for attending college, as well as actual matriculation (Cabrera \& La Nasa, 2001; Perna \& Titus, 2005).

Perna and Titus (2005) succinctly summarized the need for continued research, noting that, "the college enrollment process varies across racial/ethnic groups," but the research remains limited regarding the amount and nature of parental involvement in determining successful outcomes for students from varying racial and ethnic groups (p. 486). Perna and Titus (2005) found that parental involvement, defined as discussing academics with their children and volunteering at the school, was positively associated with college enrollment; interaction with the school over behavioral problems had the opposite effect. Altshul (2011) supported these notions, "Findings show that the positive effects of parental involvement among Mexican American parents occur through involvement in the home, whereas parental involvement in school organizations is not associated with youths' achievement" (p. 159). Frequent meetings were presumed to be a result of behavioral problems for purposes of this study, resulting in a decreased likelihood that the student whose parents frequently meet with teachers would go to a two- or four-year college.

\section{Latinos and Parental Involvement}

CRT suggests that the daily lives of Latinos are operationalized similarly to any other student applying for college, but the outcomes should not be expected to be the same. Indeed, the educational gap literature paints a picture of uninvolved parents in the Latino community; while a more nuanced approach suggests that parents are intimidated and reluctant to get involved as a result of language barriers and other school-home communication barriers. Latino parents reported feeling like they could not communicate with school officials if they were not communicating effectively in English (Zoppi, 2006). Latino parents faced additional burdens to involvement such as transportation, child care, and a general lack of communication from schools, which did not offer encouragement or support (Smith et al., 2008).

Views from the students themselves painted an even more complicated picture. According to the Pew Hispanic Center (Lopez, 2009), a survey of Latino students revealed the students themselves blamed poor parenting, rather than poor teaching, for the educational attainment gap. Such survey questions did not take into account larger questions such as students' responsibility or their ability to recognize poor teaching. In the Pew survey, $47 \%$ of respondents said, "parents of Hispanic students not playing an 
active role in helping their children succeed is a major reason [for students not performing well]" (Lopez, 2009, p. 5). Yet, the question could have been interpreted differently, as "Almost two-thirds $(65 \%)$ of Latino youth strongly agree that their parents play or played an active role in their education" (Lopez, 2009, p. 4). Thus, it appears that some parents may be active in their children's education, yet there lies a disconnect among the $18 \%$ who also stated that their parents were not necessarily helping them to succeed. It is conceivable that parental assistance does not automatically translate into positive educational outcomes for youth, Latino or otherwise (Barge \& Loges, 2003). Yet, simultaneously, students appeared to want or need that involvement.

Another recent study by the Higher Education Research Institute painted a picture of Latino students believing their parents are not as involved as the respondent would like, especially in college decision making and post-college matriculation decisions such as choice of classes (Hurtado et al., 2008). Forty-three percent of Latino freshmen reported that their parents were involved "too little" in selecting college courses, compared to $18 \%$ of whites (Hurtado et al., 2008, p. 2).

Parental involvement is difficult to quantify and disaggregate. Reading to one's children might be as important as helping with homework, but few studies ever compare the various meanings applied to parental involvement. Extant research, for example, pointed to a widening gender gap occurring within the Latino student community as a result of parents reading more frequently to their female children (Freeman, 2004). Thus, even the phrase "parental involvement" has a variety of childhood, teenage, and postcollege enrollment meanings. Parental involvement might apply to reading to children, helping with homework, assisting with college preparation, and participating in postsecondary enrollment, among many other factors. Altshul (2011), in a study specific to Mexican American youths' academic achievement, found a negative relationship between parents helping with homework and children's success. The author stated, "Parents helping with homework and whether the child was male were both negatively related to test scores (Altshul, 2011, p. 165). Checking homework could work differently than helping with homework, as checking simply implies accountability or commitment to educational requirements from the school.

Separating concepts within the parental involvement literature may ameliorate the puzzle, as Latino teens expressed differences in expectations and definitions of parental involvement in different surveys. Moreover, the history of lower levels of college attainment by Latinos in the United States puts parents in a double bind: Latinos are more likely than whites to be parenting a first-generation college student, and thus have no personal experience to rely on when being asked for advice about selecting courses, developing strong study habits, and addressing personal concerns about issues such as roommates, relationships with professors, or joining clubs. Their children express desire for their help, and they want their children to succeed, but they may feel that no (uninformed) advice is better than their best guesses. Given the operational definition offered by Zarate (2007) and others, separating academic involvement from life involvement, the following academic hypotheses are offered: 
- H2a: The more frequently parents check homework, the more likely Latino youth will be to enroll in college at any level.

- H2b: The more frequently parents check homework, the more likely Latino youth will be to enroll in bachelor's degree programs.

- H3a: The more frequently parents meet with teachers, the less likely Latino youth will be to enroll in college at any level.

- H3b: The more frequently parents meet with teachers, the less likely Latino youth will be to enroll in bachelor's degrees.

- H4a: The more frequently parents help their children with homework, the less likely Latino youth will be to enroll in college at any level.

- H4b: The more frequently parents help their children with homework, the less likely Latino youth will be to enroll in bachelor's degree programs.

\section{Rewarding Grades}

Given the need to disaggregate and operationalize parental involvement in more concrete terms, researchers are specifically reviewing how parents help or interfere with their children's ability to earn good grades. Clearly, a solid grade point average is a precursor to college enrollment and a strong stride in the educational pipeline.

Earning solid grades requires a level of commitment and motivation. Can external financial rewards motivate teens, resulting in the improved likelihood of attending college? The answer appears promising. Levitt, List, Neckermann, and Sado (2011) found that differing levels of financial rewards (larger rewards like \$20, as opposed to $\$ 10$, were more effective, particularly for male teens), as well as timing, (delayed rewards are virtually never effective) both made a difference in student success on standardized tests. Fryer (2011) examined financial incentives in three cities, and found that financial rewards were "not a panacea," but the author did find some potentially modest effects. Interestingly, financial rewards in both studies were distributed through the study, and not by parents. There is reason to suspect that financial incentives alone may not lead to college enrollment, but that rewards by parents may be more meaningful:

- H5a: Latinos whose parents reward good grades will be more likely to enroll in college at any level.

- H5b: Latinos whose parents reward good grades will be more likely to enroll in bachelor's degree programs.

Socioeconomic Status, Parental College Attainment, and Student Outcomes

Numerous studies link SES with college enrollment, typically using variables such as parental income or parental education (Zarte \& Gallimore, 2005). In surveys of Latino youth, financial stress and pressure to work were consistently cited as major factors in dropping out of school. Castellanos and Jones (2003) explained that many Latino parents were unable to assist their children with finances in college, especially in comparison to white families. The lack of financial assistance caused added strain on Latino students. 
Repeatedly, low SES was associated with being raised in a single-parent family, being held back one grade, having siblings who dropped out of high school, changing schools more than twice, and having a C average (Cabrera \& La Nasa, 2000). Importantly, Cabrera and La Nasa (2000) found that parental involvement mitigated the effect of SES in many instances, effectively narrowing the gap between lower and upper SES students. However, lower SES students, in general, lagged behind upper SES students by almost $25 \%$ with respect to high school graduation, and over $50 \%$ for those who applied to college (Cabrera, La Nasa, \& Burkum, 2001). Importantly, SES is improving for every immigrant generation that succeeds the first. In other words, secondand third-generation immigrants of any race or ethnic group surpass their parents on many SES indicators, especially wages (Haskins, 2007). Differences in SES are not clearly linked to race or ethnicity, but are significantly more complex. For example, wage increases across generations are associated with the economic situation of the country of origin. So, immigrants from less developed countries face hardships that those from developed countries never experience. The result is slower improvements in wage earnings across generations. However, Mexican immigrants, in comparison to nonimmigrants, are closer to narrow the wage gap than their parents. In 2007, a 15\% wage gap existed for second generation Mexican immigrants compared to a 32\% gap between their parents and non-immigrants in the United States (Haskins, 2007).

Parents who go to college are simply more likely to have children who go to college (Choy, 2001). The educational pipeline consists of a few key steps, starting with the decision to go to college and ending with the ACT/SAT and college application process. In each stage in the pipeline, from making the initial decision to preparing academically, parents' college attainment levels are indicative of potential success. Choy (2001) states "Graduates whose parents did not go to college were much less likely than their peers with more educated parents to complete each step" (p. 9). Lower parental college attainment is related to multiple SES factors such as the greater likelihood of being a female, a single parent, and earning a lower income (Engle, 2007). Across the board, studies indicated that first generation college students who are lower income, female, and have parents with less than a high school education were considerably less likely to enroll in postsecondary education themselves (Kuh, Kinzie, Buckley, Bridges, \& Hayek, 2006). Parental education was not only a key contributor to student educational outcomes, but was perhaps the most important variable in the educational pipeline.

- H6a: Latinos whose mother or father attended college will be more likely to enroll in college at any level.

- H6b: Latinos whose mother or father attended college will be more likely to enroll in bachelor's degree programs. 


\section{Methods}

\section{Instrumentation and Survey Objectives}

This study uses data from Wave 2 of the Texas Higher Education Opportunity Project (THEOP). Wave 1 of THEOP included surveys of over 13,000 high school seniors in a random sample of Texas public schools. In 2003, 5,836 of those seniors were reinterviewed following their senior year of high school. The second wave captured information about postsecondary education and provided information about parental involvement, family time, such as eating dinners as a family and many other variables consistent with the educational gap literature.

The survey itself was given to public high school seniors who were not attending charter schools and were not in special education. The current study followed the stated survey objectives by separately considering whites, Latinos, African Americans, and Asians. It also separately analyzed those who attended postsecondary education after high school and those who did not attend college after high school (THEOP, 2004). Respondents self-identified their membership in the four ethnic groups, and as male or female.

\section{Measures}

The frequency of family dining was measured by asking "During your senior year [in high school] did you and your parents/guardians eat dinner together as a family?" (1) Rarely or never, (2) sometimes, or (3) often or always.

The frequency of homework-checking by parents was measured by asking, "During your senior year did your parents or other adults check on your homework?" (1) Rarely or never, (2) sometimes, (3) often or always.

The frequency with which parents met with their children's teachers was measured by asking, "During your senior year, did your parents or other adults meet your teachers?" (1) Rarely or never, (2) sometimes, (3) often or always.

The frequency with which parents helped with their children's homework was measured by asking, "During your senior year, did your parents or other adults help you with your homework?" (1) Rarely or never, (2) sometimes, (3) often or always.

Parents' college attendance was measured by asking "Has your mother/father ever attended college?" (These were two separate items.) (1) Yes, (2) no.

Parents' practice of rewarding good grades was measured by asking "During your senior year did your parents or other adults reward you for good grades?" (1) Rarely or never, (2) sometimes, (3) often or always.

Students' attendance of college was measured by asking "Since September of 2002 have you attended a vocational/technical school or taken university courses for credit?" (1) Yes, (2) no. At your current institution, what type of degree, certificate, or license are you pursuing?" (0) None, (2) Associates degree, (3) Bachelors degree, (4) a license, (5) a 
certificate, (7) other. Responses to this second item were recoded in the present analyses to (0) non-bachelors degree, (1) bachelors degree.

\section{Analysis}

Logit regression, estimating the likelihood of Latino respondents attending college, was conducted. The independent variables were regressed simultaneously on: attending college at all, and attending college in pursuit of a bachelor's degree. A concern was that the variables may be correlated at a level which could create a multicollinearity problem. To examine this issue, a correlation analysis was run on the independent and dependent variables used in the study. For the correlation analysis, results were reported using the "bachelor's degree," but similar results using "any college" as the dependent variable was also found. The correlation analysis was reported in Table 1 .

A number of the independent variables were correlated. Not surprisingly, the highest correlation between two independent variables was between "parents check homework" and "parents help with homework" $(\rho=0.42)$. To account for any possible multicollinearity that this might induce, a new variable was created, "homework," which was a linear combination of the two. The other independent variables, while correlated, did not rise to the level that warrants concern regarding multicollinearity.

\section{Results}

The first hypotheses predicted that: in families that eat together regularly, Latinos were more likely to enroll in college. This hypothesis was not supported in either the "any college" $(\mathrm{B}=.10, \mathrm{p}=.12)$ or "bachelor's degree" $(\mathrm{B}=.05, \mathrm{p}=.07)$ condition. (See Table 2).

$\mathrm{H} 2 \mathrm{a}-4 \mathrm{~b}$ involved parental involvement in Latinos' high school education, predicting that more involvement is generally associated with less likelihood of college attendance. The test of the second and fourth hypotheses relied on the new variable, "homework," which was the combination of the two homework variables. The separate homework hypotheses, checking homework and helping with homework, were not supported. This finding could be related to a correlation between the two variables, both capturing the same underlying construct. Using the combined homework variable, that parents' regular involvement in homework should predict college attendance, was strongly significant and negative in both the "any college" condition $(\mathrm{B}=-.12, \mathrm{p}<.001)$, or in the "bachelor's degree" condition $(\mathrm{B}=-.13, \mathrm{p}<.001)$. Checking and helping with homework are, therefore, taken as one construct, and they pointed to a negative association between parental involvement in homework and college matriculation.

The fifth hypothesis predicted that Latinos whose parents rewarded good grades were more likely to attend college. For this hypothesis the coefficient on "any college" ( $\mathrm{B}=$ $.07, \mathrm{p}=.15$ ) was positive, but insignificant. However, it was significant and positive when measuring the outcome as "bachelor's degree" $(\mathrm{B}=.15, \mathrm{p}=.03)$. 
Table 1 Correlation Analysis

\begin{tabular}{|c|c|c|c|c|c|c|c|}
\hline & $\begin{array}{c}\text { Bachelor } \\
\text { degree }\end{array}$ & $\begin{array}{l}\text { Family dines } \\
\text { together }\end{array}$ & $\begin{array}{l}\text { Parents check } \\
\text { homework }\end{array}$ & $\begin{array}{c}\text { Parents meet } \\
\text { teachers }\end{array}$ & $\begin{array}{l}\text { Parents help } \\
\text { with homework }\end{array}$ & $\begin{array}{l}\text { Mother attended } \\
\text { college }\end{array}$ & $\begin{array}{l}\text { Father attended } \\
\text { college }\end{array}$ \\
\hline Family dines together & 0.01 & & & & & & \\
\hline Parents check homework & $-0.06^{*}$ & $0.23^{* * *}$ & & & & & \\
\hline Parents meet teachers & -0.02 & $0.11 * * *$ & $0.24 * * *$ & & & & \\
\hline Parents help with homework & -0.03 & $0.17 * * *$ & $0.42 * * *$ & $0.29 * * *$ & & & \\
\hline Mother attended college & $0.13 * * *$ & $-0.04 *$ & 0.01 & -0.02 & $0.05^{*}$ & & \\
\hline Father attended college & $0.17 * * *$ & -0.01 & 0.00 & -0.02 & 0.02 & $0.49 * * *$ & \\
\hline Parents reward good grades & 0.03 & $0.20 * * *$ & $0.32 * * *$ & $0.15^{* * *}$ & $0.25^{* * *}$ & 0.03 & 0.01 \\
\hline
\end{tabular}


Table 2 Logit Analysis of Effects of Family Circumstances on Latinos' Odds of Attending College or a Bachelor's Degree Program $(N=1,607)$

\begin{tabular}{llccc}
\hline & \multicolumn{2}{c}{ Any College } & \multicolumn{2}{c}{ Bachelor Degree Program } \\
Family Circumstance & Odds & Std. Error & Odds & Std. Error \\
\hline Family dines together & 0.10 & 0.07 & 0.05 & 0.07 \\
Parents check homework & $-0.12^{* * *}$ & 0.04 & $-0.13^{* * *}$ & 0.04 \\
Parents meet teachers & -0.07 & 0.07 & -0.01 & 0.07 \\
Mother attended college & $0.39^{* * *}$ & 0.15 & $0.36^{* * *}$ & 0.15 \\
Father attended college & $0.54^{* * *}$ & 0.09 & $0.70^{* * *}$ & 0.15 \\
Parents reward good grades & 0.07 & 0.07 & $0.15^{* *}$ & 0.07 \\
Constant & -0.05 & 0.22 & $-0.69^{* * *}$ & 0.22 \\
Pseudo R-Square & \multicolumn{2}{c}{0.03} & \multicolumn{2}{c}{0.03} \\
Chi-Square & \multicolumn{5}{c}{$59.01 * * *$} \\
\hline$* * \mathrm{p}<.011^{* * *} \mathrm{p}<.001$ & \multicolumn{5}{c}{} \\
\hline
\end{tabular}

Finally, the sixth hypothesis predicted that parents' college attendance increased the likelihood of Latinos attending college. The results were strongly consistent with this hypothesis. Using "any college" as the outcome variable, the coefficients for both parents having a college degree were strongly positive (Mother, $\mathrm{B}=.39, \mathrm{p}<.001$; Father, $\mathrm{B}=$ $.54, \mathrm{p}<.001)$. The results when measuring the outcome as "bachelor's degree" also strongly supported the hypothesis, Mother $(\mathrm{B}=.36, \mathrm{p}=.01)$ and for Father $(\mathrm{B}=.70, \mathrm{p}<$ $.001)$.

\section{Limitations}

The limitations of this study fall under three main categories: disaggregating race and ethnicity, quantifying the parent-teacher relationship, and the lack of SES-related parental variables in the dataset. First, race is socially constructed according to CRT, and this component of the framework highlights one of the main limitations of the current study. Given the existing data set, it is virtually impossible to distinguish among different groups of Latinos. The experiences of those from different countries and ethnic backgrounds would present a more meaningful analysis. By grouping all Latinos in the study, along with the fact that the data are limited to the State of Texas, the analytical framework itself becomes limited; that is to say, a nuanced approach is not offered, and therefore presents the social construction of Latinos as one monolithic group.

Another limitation of the current study is the lack of clarity in the survey regarding parental interaction with teachers. Unfortunately, the data do not offer details on the quality or types of interactions that occur when parents meet with teachers. 
The current study is also limited in SES analyses, as parental income is not a variable in the dataset. However, parental education is analyzed.

\section{Implications for Social Workers, Parents, and Educators}

Parents attending college and parents rewarding for good grades are both positive factors in Latino youths' matriculation into postsecondary education. When parents helped with homework or met with teachers, the odds of college attendance diminished. The message to parents is that modeling education oneself and positively rewarding for their children's accomplishments is important. The message is not that parents should avoid teachers and not check homework. The results most likely indicate that those parents who felt the need to meet frequently with teachers, or were overly involved in homework, may have been doing so to ameliorate poor academic performance. However, those attempts by parents are potentially less useful than rewarding their children given the findings in this study.

The measures of parental involvement in this study (help with or checking homework, and meeting with teachers) were, in all cases, negatively related to college attendance. Barge and Loges (2003) found complex differences in understanding the role and benefit of "parental involvement" in children's schooling between parents, middle school students, and teachers. Students clearly distinguished different kinds of "help with homework" and rewards for good performance; therefore it could be that the present study's measures of the role of parents in homework was too blunt an instrument to capture the different ways children interpret parents' attempts to help. Barge and Loges (2003) reported that teachers and students distinguished between parent/teacher meetings that were generally helpful and those that were not. For instance, students reported embarrassment if parents appeared at school in situations where the students were being punished, and teachers reported that parents who only appeared at school when their children were in trouble were not generally helpful. Parental involvement may, therefore, include very simple accommodations by educators, such as: weekly communication regarding assignments, grades, and school functions written in English and Spanish. Simply receiving the information more frequently allows parents to ask, as well as, reward positive performance. For parents who cannot afford to reward, programs that do reward grades are being implemented through grants and school initiatives.

Rewarding for grades is a relatively new programmatic innovation that is taking root across the country. A few federal and foundation-funded grants are including grade rewards in the program implementation process. As a matter of policy, blindly rewarding for grades may not produce the intended results. Further examination by policymakers should entail consideration of the source. Are financial incentives as meaningful coming from a federal program or one's own parents? Such questions require further examination, but this study suggests that parental involvement in rewards is meaningful. In addition to grade rewards, the National Conference of State Legislatures now recommends financial rewards for Latinos' successful graduation from high school (Camacho Liu, 2011). 
Policymakers, public managers, and social workers should also be aware of such recommendations, as implementation of public policies requires consideration across race or ethnicity. This study is limited in its ability to assess school-factors in the CRT framework. Would parents be more involved if schools were more accommodating? Or, are Latino parents working long hours and are simply prevented from becoming overly involved in schools during limited school hours? Indeed, one study of a promising program that involved Latino parent involvement proved puzzling to the program operators. Parents who said they would attend an evening session at the school failed to show. Social workers quickly learned that the local factory had let the workers out late that evening. "The situation highlighted the tenuous working conditions that Latino parents in the country face" (Belliveau, 2011, p. 89). In another study, the overwhelming majority of Latino fathers reported that their job was the single biggest obstacle to parenting (Shears, Furman, \& Negi, 2002). Public and school-based policies that consider cultural aspects of families offer promise. For example, the National Conference of State Legislatures recommends that schools in the United States accommodate Latino families by offering classes in the evening, on weekends, or online to help working teens who may be expected to help the family (Camacho Liu, 2011). Zarate (2007) recommends public policies allowing flexible work time for parents of school age children. The College Board also recommends rewarding high schools that send more Latinos to college (Nevarez \& Rico, 2007).

What works? Cultural sensitivity is clearly important, but structural changes to a generally inflexible educational system as demographics shift in the United States is a topic that warrants some thought as well. Indeed, many families, Latino or otherwise, across the United States face employment pressures that interfere with parental involvement. Rather than continuing to rely on parents to augment their children's education, some schools are already lengthening the school day, providing free tutoring after school, and allowing children to complete their homework at school. Some innercity schools are now open on the weekends. Washington, DC, for example, opened the first public boarding school in the country (http://www.seedschooldc.org). The move away from parental involvement to an educational system ready to serve more than the educational needs of students is a quickly growing phenomenon. The SEED school, as one example of a lottery-based system, is associated with increased earnings and reduced chances of being involved in a crime for students after one year of attendance (Curto \& Fryer, forthcoming). Students in SEED must also apply to at least five colleges as a condition of graduation (Curto \& Fryer, forthcoming).

Policymakers and social workers might also consider the most important variable in this study and in so many others: parental education. Working with youth to promote college may translate into working with families to improve overall educational attainment. Programs that work with both youth and their parents are commended as promising programs. Southern Methodist University, for example, offers a Master's in Bilingual Education that has graduated over 300 Latino students who now work with over 60,000 youth and their parents. The factors that help students find their way through the educational pipeline are inherently present in the middle and upper classes of society. In the last decade, federal initiatives to create Individualized Development Accounts 
(IDAs) or savings accounts for education or entrepreneurship are on the rise. Encouraging and supporting educational attainment cannot be understated. Programs such as, Advancement Via Individual Determination (AVID) or Puente Project are recognized in educational circles as best practices (Nevarez \& Rico, 2007). Such programs, designed specifically for youth whose parents did not attend college, offer day-to-day instruction regarding college matriculation. These programs attempt to combat negative influences experienced by students in a CRT framework. These programs, and many others like them, can be adopted in more formal settings in schools to promote college matriculation.

Realistically, large-scale changes in public policy are always difficult. But given the findings from this research, smaller, close-to-home approaches are viable. Providing allowances for grade rewards through existing federal and private programs could conceivably improve both parental involvement, as well as continued success in school. Gradual changes by schools, government, and families have potential to increase success for young students in the college matriculation process. Finding "what works," rather than repeatedly focusing on "the educational gap" can become the new policy focus for Latinos in the United States.

\section{References}

Altschul, I. (2011). Parental involvement and the academic achievement of Mexican American youths: What kinds of involvement in youths' education matter most? Social Work Research, 39(3), 159-170.

Barge, J. K., \& Loges, W. E. (2003). Parent, student, and teacher perceptions of parental involvement. Journal of Applied Communication Research, 31(2), 140-163.

Baum, S., \& Flores, S. M. (2011). Higher education and children in immigrant families. The Future of Children, 21(1), 171-193.

Belliveau, M. (2011). Interdisciplinary service-learning: Building student competencies through the Cross-Cultural Parent Groups Project. Advances in Social Work, 12(1), 79-93.

Brindis, C., Driscoll, A., Biggs, M., \& Valderrama, L. (2002). Fact sheet on Latino youth: Education. San Francisco, CA: University of California.

Burnsed, B. (2011, August 5). How higher education affects lifetime salary: College degrees significantly boost earning, but women and minorities benefit less. US News and World Report. Retrieved from http://www.usnews.com/education/bestcolleges/articles/2011/08/05/how-higher-education-affects-lifetime-salary

Cabrera, A., \& La Nasa, S. (2000). Understanding the college choice of disadvantaged students. New Directions for Institutional Research. San Francisco, CA: Jossey-Bass.

Cabrera, A. F., La Nasa, S., \& Burkum, K. (2001). Pathways to a Four-Year Degree: The Higher Education Story of One Generation. Retrieved from http://www.education.umd.edu/Depts/EDPA/faculty/cabrera/Pathway $\% 20$ to $\% 20 \mathrm{a} \% 2$ 0Four-Year\%20Degree.pdf 
Camacho Liu, M. (2011). Investing in higher education for Latinos: Trends in Latino college access and success. Denver, CO: Retrieved from http://www.ncsl.org/documents/educ/trendsinlatinosuccess.pdf

Carnevale, A. P., Rose, S. J., \& Cheah, B. (2010). The college payoff: Education, occupation, and lifetime earnings. Washington, DC: The Georgetown University Center on Education and the Workforce.

Castellanos, J., \& Jones, L. (Eds). (2003). The Majority in the minority: Expanding the representation of Latina/o faculty, administrators and students in higher education. Sterling, VA: Stylus Publishing.

Choy, S. (2001). Students whose parents did not go to college: Postsecondary access, persistence, and attainment. Washington, DC: U.S. Department of Education, Retrieved from http://nces.ed.gov/pubs2001/2001126.pdf

Curto, V., \& Fryer, R. (forthcoming). The potential of urban boarding schools for the poor: Evidence from SEED. Journal of Labor Economics.

Delgado, R., \& Stefancic, J. (2012). Critical race theory: An introduction. New York, NY: NYU Press.

Eisenberg, M. E., Olson, R. E., Neumark-Sztainer, D., Story, M., \& Bearinger, L. H. (2004). Correlations between family meals and psychosocial well-being among adolescents. Archives of Pediatrics and Adolescent Medicine, 158(8), 792-796.

Engle, J. (2007). Postsecondary access and success for first-generation college students. American Academic, 3, 25-46. Retrieved from http://www.aft.org/pdfs/highered/academic/january07/Engle.pdf

Freeman, C. E. (2004). Trends in Educational Equity of Girls \& Women: 2004 (NCES 2005-016). U.S. Department of Education, National Center for Education Statistics. Washington, DC: U.S. Government Printing Office. Retrieved from http://nces.ed.gov/pubs2005/2005016.pdf

Froiland, J., Peterson, A., \& Davison, M. (2013). The long-term effects of early parent involvement and parent expectation in the USA. School Psychology International, 34(3), 33-50.

Fry, R. (2011). Hispanic college enrollment spikes, narrowing gaps with other groups. Washington, DC: Pew Research Center. Retrieved from http://www.pewhispanic.org/2011/08/25/hispanic-college-enrollment-spikesnarrowing-gaps-with-other-groups/

Fryer, R. (2011). Financial incentives and student achievement: Evidence from randomized trials. The Quarterly Journal of Economics, 126(4), 1755-1798.

Haskins, R. (2007). Economic mobility of immigrants in the United States. Washington, DC: Brookings Institution. Retrieved from http://www.brookings.edu/ /media/research/files/reports/2007/7/useconomics\%20ha skins/07useconomics haskins.pdf 
Henderson, A., \& Mapp, K. (2002). A new wave of evidence: The impact of school, family, and community connections on student achievement. Annual Synthesis 2002. Austin, TX: National Center for Family and Community Connections with Schools. Retrieved from http://www.sedl.org/connections/resources/evidence.pdf

Hurtado, S., Sáenz, V. B., Santos, J. L., \& Cabrera, N. L. (2008). Advancing in higher education: A portrait of Latina/o college freshmen at four-year institutions: 19752006. Los Angeles: Higher Education Research Institute, UCLA. Retrieved from http://www.heri.ucla.edu/PDFs/pubs/briefs/brief-20081015-LatinoTrends.pdf

Izzo, C. V., Weissberg, R. P., Kasprow, W. J., \& Fendrich, M. (1999). A longitudinal study of the relationship between parent-school partnerships and school adjustment among urban elementary school children. American Journal of Community Psychology, 27(6), 817 - 840.

Koebler, J. (2011, May 2). White House calls for improved Hispanic education. US News and World Report. Retrieved from http://www.usnews.com/education/blogs/highschool-notes/2011/05/02/white-house-calls-for-improved-hispanic-education

Kuh, G., Kensie, J., Buckley, J., Bridges, B., \& Hayek, J. (2006). What matters to student success: A review of the literature. National Postsecondary Educational Cooperative. Retrieved from http://nces.ed.gov/npec/pdf/kuh_team report.pdf

Levitt, S., List, J. A., Neckermann, S., \& Sado, S. (2011). The impact of incentives on short-term student performance. Unpublished White Paper. Retrieved from http://bfi.uchicago.edu/events/20111028 experiments/papers/Levitt_List_Neckerman n Sadoff_Short-Term_Incentives_September2011.pdf

Lopez, M. H. (2009). Latinos and education: Explaining the attainment gap.

Washington, DC: Pew Hispanic Center. Retrieved from http://www.pewhispanic.org/files/reports/115.pdf

Maxwell, S., \& Connell, N. (2013). Post-secondary matriculation for minority high school youth: Multicultural mentoring and student engagement. The Quest: Journal of Higher Education, 2(1), 20-31.

National Center on Addiction and Substance Abuse at Columbia University (CASA). (2003). The importance of family dinners III. New York, NY, Columbia University.

National Center on Addiction and Substance Abuse at Columbia University (CASA). (2011). The importance of family dinners VII. New York, NY: Columbia University.

National Center for Education Statistics. (2003). Status and trends in the education of Hispanics (NCES 2003-008). Washington, DC: NCES.

National Center for Education Statistics. (2011). The Condition of Education 2011. NCES 2011-033. May. Washington, DC: National Center for Education Statistics. Retrieved from http://nces.ed.gov/pubsearch/pubsinfo.asp?pubid=2011033

National Women's Law Center (NWLC) \& Mexican American Legal Defense and Educational Fund (MALDEF). (2009). Listening to Latinos: Barriers to high school 
graduation. Washington, DC: NWLC. Retrieved from

http://maldef.org/assets/pdf/ListeningtoLatinas.pdf

Nevarez, C., \& Rico, T. (2007). Latino education: A synthesis of recurring recommendations and solutions in P-16 education. New York, NY: College Board. Retrieved from http://www.collegeboard.com/prod downloads/prof/counselors/Latino-Education-ASynthesis.pdf

Perna, L., \& Titus, M. (2005). The relationship between parental involvement as social capital and college enrollment: An examination of racial/ethnic group differences. The Journal of Higher Education, 76(5), 485-518.

Perna, L. W. (2006). Studying college choice: A proposed conceptual model. In J. C. Smart (Ed.), Higher Education: Handbook of theory and research (pp. 99-157). The Netherlands: Springer, XXI.

Portes, A., Fernández-Kelly, P., \& Haller, W. (2009). The adaptation of the immigrant second generation in America: A theoretical overview and recent evidence. Journal of Ethnic and Migration Studies, 35(7), 1077-1104.

Rowan-Kenyon, H. T., Bell, A., \& Perna, L. W. (2008). Contextual influences on parental involvement in college going: Variations by socioeconomic class. Journal of Higher Education, 79(5), 564-586.

Schneider, B., Martinez, S., \& Owens, A. (2006). Barriers to educational opportunities for Hispanics in the U.S. In M. Tienda \& F. Mitchell (Eds.), Hispanics and the future of America (pp. 179-221). Washington, DC: National Academies Press.

Shears, J., Furman, R., \& Negi, N. J. (2008). The perceptions of Mexican-American men as fathers. Advances in Social Work, 8(2), 338-352.

Smith, J., Stern, K., \& Shatrova, Z. (2008). Factors inhibiting Hispanic parents' school involvement. Rural Educator, 29(2), 8-14.

Texas Higher Education Opportunity Project. (2004). Methodology report. Retrieved from http://theop.princeton.edu/surveys/senior w2/senior w2 methods pu.pdf

Tienda, M. (2009). Hispanicity and educational inequality: Risks, opportunities and the nation's future. American Association of Hispanics in Higher Education. Princeton, NJ: Educational Testing Service. Retrieved from http://www.ets.org/Media/Research/pdf/PICRIVERA1.pdf

Tienda, M., \& Mitchell, F. (2006). Multiple origins, uncertain destinies: Hispanics and the American future. Washington, DC: National Academy Press.

U. S. Census Bureau. (2008). US population projections. Retrieved from http://www.census.gov/population/www/projections/downloadablefiles.html

Zarate, M. E. (2007). Understanding Latino parental involvement in education: Perceptions, expectations and recommendations. Los Angeles, CA: Tomás Rivera Policy Institute. 
Zarate, M. E., \& Burciaga, R. (2010). Latinos and college access: Trends and future directions. Journal of College Admission, 209, 24-29. Retrieved from http://www.eric.ed.gov/ERICWebPortal/search/detailmini.jsp? nfpb=true\&_\&ERIC ExtSearch_SearchValue 0=EJ906627\&ERICExtSearch_SearchType $0=$ no\&accno= $\underline{\text { EJ906627 }}$

Zarate, M. E., \& Gallimore, R. (2005). Gender differences in factors leading to college enrollment: A longitudinal analysis of Latina and Latino students. Harvard Educational Review, 75(4), 383-408.

Zoppi, I. M. (2006). Latino parental involvement in students' school attendance and achievement. Region II District of Prince George's County Public Schools research report. Retrieved from http://www.education.umd.edu/mimaue/documents/publications/latparinvstd.pdf

\footnotetext{
'The THEOP data used the terms "Mexican, Mexican American, or Chicano." I am using the term Latino to represent the cultural reference to Spanish-speaking populations or their descendants.
}

\section{Author note:}

Address correspondence to: Sarah P. Maxwell, Ph.D., Associate Professor of Public Affairs, School of Economic, Political \& Policy Sciences, The University of Texas at Dallas, 800 W. Campbell Road, GR 31, Richardson, Texas 75080-3021. Email: sarah.maxwell@utdallas.edu 